\title{
The Amazon and the Internationalisation of Chinese Companies
}

\author{
Rubia Cristina Wegner* \\ Marcelo Pereira Fernandes**
}

\begin{abstract}
The objective of this article is to analyse the announced and ongoing foreign direct investment of companies from China in the Amazon region, mainly in Brazil, which covers most of the region, and Peru. We will also to a certain extent include the Amazon region that crosses Colombia and Ecuador. These countries constitute one of the centres of South American integration due to their infrastructure, and the construction of a highway linking Peru and Brazil to the Pacific has been planned. Segments such as mining, petroleum and grains have been the target for the productive internationalisation of Chinese companies. In the analysed countries, the volume of announced and ongoing direct investment of Chinese companies is indeed significant, targeting the above-mentioned natural resource industries. The large infrastructure project announced will be a logistical support for the companies that announced investments in the Amazon, especially between Brazil and Peru. Even though these countries and the other five that share the Amazon rainforest have presented some proposals of co-operation, they have not developed a common approach for the reception of investments from Chinese companies.
\end{abstract}

Keywords: Foreign Direct Investment; Chinese Multinational Company; Amazon; Internationalisation; Integration.

\section{Introduction}

Developing countries were initially the preferred recipients of foreign investments, even though Chinese state-owned enterprises have acquired shares of companies in developed countries, such as the USA and European Union countries (Karreman, Burger and Oort 2016). Since 2010, foreign direct investment (FDI) by Chinese companies in South American countries has increased considerably. ${ }^{1}$ Between 1990 and 2009, countries such

* Federal Rural University of Rio de Janeiro (UFRRJ), Seropédica-RJ, Brazil; rubicawegner@gmail.com. ORCID iD 0000-0002-4824-8414.

** Federal Rural University of Rio de Janeiro (UFRRJ), Seropédica-RJ, Brazil; mapefern@gmail.com; ORCID iD 0000-0003-4550-8564. 
as Argentina and Brazil received, respectively, US\$143m and US\$255m. Only in 2010 did the inflow of Chinese FDI rise to US\$3.1b in Argentina and US\$9.6b in Brazil (ECLAC 2015). Other countries in the region became hosts of greater volumes of investments from Chinese companies after 2010. Peru, for example, received US $\$ 84 \mathrm{~m}$ in 2010 and US $\$ 4.6 \mathrm{~b}$ in 2013 (ECLAC 2015). The motivations of Chinese companies, especially to invest in developing countries, have been the subject of a variety of studies - as will be seen in the first section of this article - which have converged to point to, among other motivations, the need of this Asian country to obtain access to raw materials and sustain its long-term development project.

The Amazon forest, strictly speaking, penetrates the territories of the following South American countries: Venezuela, Ecuador, Peru, Colombia, Brazil, Bolivia, Suriname and Guyana. Countries such as Suriname, Guyana, and Venezuela can be identified as the pioneers in hosting investments from Chinese companies, and in infrastructure services (Abdenur and Souza Neto 2013; Abdenur 2013). However, these countries and Bolivia will not be analysed in this article for two main reasons: (i) Venezuela, Suriname and Guyana hold specific economic relations with China that deserve their own study and (ii) Bolivia, for the time being, is not prominently reported for the reception of Chinese investments. In this article, Chinese direct investments will be investigated for the Amazon, mainly in Brazil and Peru and, to some extent, Ecuador and Colombia.

As it is one of the most attractive regions in terms of the exploration of natural resources and, at the same time, in terms of the implementation and deepening of measures of environmental conservation and preservation, movements such as the expansion of investments of multinational companies must be better understood and described. In addition, since it involves a large part of the South American territory, the countries of the region would be expected to maintain some kind of common strategy regarding FDI, notably from Chinese companies. This article seeks to systematise study of the Chinese presence in countries of the Amazon, describing its main movements in terms of direct investments. Thus, the purpose of this article is to present this dynamic in light of Chinese multinational companies. A more in-depth discussion on the socio-environmental impacts of Chinese companies' investment, and on national geopolitical and economic development aspects, are part of the discussion presented in this paper but are not fully detailed. Likewise, when natural resources are mentioned, it will be concerning mining, agribusiness and petroleum. The article does not intend to carry out an exhaustive discussion about the concept of natural resources and the consequences of their economic exploration.

Besides this introduction and the final considerations, the article is composed of three other sections. In the second, a theoretical discussion on the phenomenon of expansion of Chinese companies' direct investment is presented, in the third, this phenomenon is analysed as regards the countries of the South American Amazon. We would like to note that the number of references is due to the need to detail the sources of Chinese companies' investment, and a description of the 'Chinese presence.' 


\section{The expansion of Chinese multinational companies to developing countries: some considerations}

Multinational companies of developing countries began to be analysed as early as the 1980s, especially by Lall (1984). In the twenty-first century, they should be considered consolidated players in the dynamics of global capitalism, both in the case of Chinese companies and in the case of companies from countries such as Brazil, India and Russia - the BRICS in general. Especially regarding China, theoretical analyses and explanations have focused on three basic areas: (i) studies to determine the motivations and format of Chinese multinational companies' foreign investment in hosts that are developing countries (Morris et al 2002; Buckley et al 2007; Cheung and Qian 2009; Kolstad and Wiig 2012; Lin 2015); (ii) the effects of this 'Chinese presence' on promoting economic development of hosts (Cheng and Ma 2010; Jenkins 2011; Armony and Strauss 2012; Kotschwar and Muir 2012); and (iii) the international competition capacity of Chinese multinational companies or the predominance of long-term national development goals in their business strategies (Rugman and Li 2007; Carmody and Owusu 2011; Ellis 2012; Morris et al 2012; Medeiros and Cintra 2015). There is also a fourth group, which seeks to identify trajectory or activity patterns of Chinese multinational companies (Boisot and Meyer 2008).

Let us mention some examples regarding these analytical currents. Authors such as Carmody and Owusu (2011) conceive the Chinese presence (in terms of capital inflows) in African countries - such as Zimbabwe, Ghana, Zambia and South Africa - as a form of development co-operation. Lyman (2005) understands it in the opposite way, i.e., that it is the usual exploitation relationship of the colonising European countries and the USA. Bräutigam and Xiaoyang (2012) believe that, from their state-owned enterprises (SOEs) China has built a diplomacy aimed at promoting the economic development of the host country, even when it comes to the exploration of natural resources. Authors such as Ellis (2012) and Medeiros and Cintra (2015) associate the motivations and operation of these companies with the Asian country's long-term national economic development needs, such as access to food and energy sources. Authors such as Huang and Wang (2011) consider that the investment motivations of Chinese multinational SOEs in developing countries can be explained by the supposed institutional weakness of the latter. From this perspective, there are also scholars - such as Cheung and Qian (2009) - who explain this phenomenon with the conventional theoretical approach. Especially regarding Latin American countries, Mellor (2012) believes the Chinese central government has a specific intention to privilege countries that receive less FDI flows from western transnational corporations.

Overall, the studies on Chinese multinational companies present the underlying perspectives of 'Chinese state pragmatism' versus 'benefits from multinational SOEs' investment in host developing economies.' Dunning (2010) argues that China and India have redrawn the spatial configuration of world economic activity in the $21^{\text {st }}$ century through their multinational companies. Kato (2013), by empirically evaluating the strategies of the Chinese construction multinationals through semi-structured interviews, states that tra- 
ditional theories no longer explain the trajectory and operation of these companies. Boisot and Meyer (2008) consider that the motivation of these companies to invest in developing countries is an open question. According to Chen (2015), theoretical-explanatory analysis must increasingly come to understand the Chinese multinational company not as being able or not being able to compete internationally (Rugman and Li 2007), but to recognise that these companies have accumulated technological and management capabilities (Van Agtmael 2007).

According to Liou (2009), the analyses of multinational SOEs commonly consider the Chinese state as the sole rational actor and planner of their operation in host countries, which is an incomplete perspective of this matter. On the other hand, the advance of Chinese multinational enterprises to developing countries exposes the transformation of the world economy towards China as the centre of gravity of economic growth.

\section{Multinational companies from developing countries investing in developing countries: the context of the China-Amazon economic relationship}

Data released by Chinese official sources are not generally considered reliable. Companies understate figures negotiated in FDI operations to avoid taxes, while the government is interested in overstating disclosed data to influence the perception regarding the Chinese economic performance. In fact, data from the Ministry of Commerce, People's Republic of China (MOFCOM) represent the investment intentions of Chinese companies and not their implementation. Frischtak et al (2013) explain that the MOFCOM compiles its data employing an administrative approach that uses information provided by companies when they record their investments. The two problems of this procedure are: (i) statistics reflect approved projects rather than actual flows, without counting companies that avoid government approval; (ii) the Chinese government does not require companies to disclose the final destination of their investments. The authors also explain that the round-tripping phenomenon - FDI flow that leaves and returns to the country through an offshore location - inflates the Chinese investments disclosed by official sources. The other sources, UNCTAD, the World Bank and the Central Bank also experience this problem, since they use the MOFCOM bulletin.

Academic studies on this matter have sought complementary tools for data collection besides those of official bodies. These tools, listed in Frischtak et al (2013), are: the monitoring of specialised media that announces changes and decisions about Chinese investment; interviews with company directors, government agencies, business associations and embassies in order to map investment projects; analysis of companies' financial records and other documents (institutional reports) that evidence flows of Chinese foreign investment. In general, academic studies on Chinese companies' investment in natural resources in Africa, Latin America and Antarctica - also in Canada and Australia - have used data analysis as their basic methodological tool, combined with bibliographical and documentary research (Kotschwar and Muir 2012; Abdenur and Souza Neto 2013; Cintra 2013; Frischtak et al. 2013). 
In this direction, other studies can be cited. Karreman, Burger and Oort (2016) used fDi Markets (2003-2010), from the Financial Times, and the European Investment Monitor (2003-2009), from EY consultancy, as data sources to analyse the location choices of Chinese multinationals in Europe. Both sources contain information on greenfield investment projects announced in the media by companies, financial information providers, etc. Andreff (2016) used the MOFCOM Statistical Bulletin and bibliographic sources such as Salidjanova (2011) to collect data on Chinese companies and compare the strategies of multinationals of the BRICS countries. Kimura (2013) analysed the performance of Chinese multinational companies in South Africa based on interviews with representatives of the MOFCOM, company employees, and research professors from South African universities.

That said, this article will describe and analyse multinational companies' investment based on sources documented in the press and on websites specialised in publishing business information.

The data presented in Table 1 were tabulated within the scope of studies carried out by ECLAC researchers. Tabulation was made through a systematic monitoring of investments announced by Chinese companies and investments effectively realised. The expansion of Chinese investments in the region is well known. Based on Chen and Pérez Ludeña (2014), Chinese investments represented $11 \%$ of the total received by Latin America in 2010. In South America, Brazil stands out as a destination for Chinese companies' direct investment as of 2009 (Table 1): it increases from US\$255m between 1990 and 2009 to US $\$ 9.5 b$ in 2010 and US\$2.6b in 2013. At the same time, countries such as Peru, Ecuador and Colombia received considerably larger amounts than Brazil between 1990 and 2009; however, they have reduced their participation in these flows in the last three years. In fact, Table 1 suggests that Brazil has become the main recipient of Chinese companies' investment in recent years (until 2013), while from 1990 to 2009, Peru was the South American country where these companies most invested. Table 1 shows that, from 1990 to 2009, countries with territories in the Amazon corresponded to $91.7 \%$ of the FDI of Chinese companies for South America and 91.8\% in 2012. It should be noted that these flows did not specifically target the Amazon, although it can be observed that these countries are increasingly preponderant for China's FDI expansion trajectory.

The effects of the Chinese state going out strategy to support the internationalisation of its companies in terms of FDI expansion in South America are evident, as the data in Table 1 suggest. In the same way that Brazil and Peru have presented themselves as preferential countries for Chinese companies' investment, Brazil, the most diversified economy in the region, concentrated just over 50\% of these FDI flows. Nevertheless, there are doubts and ambiguities regarding the induction of productive chaining based on Chinese companies' investment in these countries.

The scepticism about the 'possibility of economic development' offered by Chinese companies' FDI is based on the assumption that the only possible strategy for countries that are rich in natural resources is to offer those resources to any multinational company interested in their economic exploration. In exchange, they would be conniving 
with the most diverse forms or levels of authoritarianism and economic policy discretion. González-Vicente (2013) considers that such scepticism comes from at least two understandings: (i) opposition between western and eastern business models, since Chinese multinational companies do not invest to make a profit, but to respond to state interests; (ii) the state of countries that are rich in natural resources are merely rentier states. It would not be wrong to summarise these understandings by saying that western capitalist companies are efficient because they follow market principles and clearly define the game rules. In contrast, the public policies of host countries are not in line with their national productive and business strategies when dealing with the 'Chinese presence.'

Table 1 - Flows of Chinese direct investment in the Amazon - 1990-2013 (in US\$ million)

\begin{tabular}{llllllll}
\hline Unit & $\mathbf{1 9 9 0 - 2 0 0 9}$ & $\mathbf{2 0 1 0}$ & $\mathbf{2 0 1 1}$ & $\mathbf{2 0 1 2}$ & $\mathbf{2 0 1 3}$ & Total per unit & $\%$ \\
\hline Brazil & 255 & 9563 & 5676 & 6066 & 2580 & 24140 & $50.1 \%$ \\
Peru & 2262 & 84 & 829 & 1307 & 4626 & 9108 & $18.9 \%$ \\
Ecuador & 1619 & 45 & 59 & 86 & 88 & 1897 & $3.9 \%$ \\
$\begin{array}{l}\text { Colombia } \\
\text { Amazon* }\end{array}$ & 1677 & 6 & 293 & 996 & 776 & 3748 & $7.8 \%$ \\
$\begin{array}{l}\text { Total Latin } \\
\text { America ** }\end{array}$ & 6342 & 13712 & 9309 & 9206 & 9624 & 48193 & -- \\
$\begin{array}{l}\text { Participation } \\
\text { of the Amazon }\end{array}$ & $91.7 \%$ & $70.7 \%$ & $73.7 \%$ & $91.8 \%$ & $83.9 \%$ & $81.0 \%$ & -- \\
\hline
\end{tabular}

Source: Created by the authors based on data tabulated by Miguel Perez-ECLAC.

*Data available only for Brazil, Colombia, Ecuador and Peru.

**Argentina, Brazil, Peru, Ecuador, Venezuela, Colombia, Chile and Guyana.

\section{Natural resources and FDI: Chinese companies in the Amazon}

In this section, the objective is to place the Amazon in the economic and political context of South America and to highlight the presence of Chinese companies in the countries considered. In the first subsection, the Amazon is analysed considering its natural resources and the co-operation initiatives among South American countries. This analysis was developed considering the Amazon as a strategic geopolitical space for South America, especially when there is an increase of multinational investments in the rainforest. In the subsection on Chinese investments in the Amazon, the investments announced by Chinese multinational companies in Brazil, Colombia, Ecuador, and Peru, whose epicentre is the Amazon, are listed and described.

\section{The Amazon in the context of South American integration strategies}

Figure 1 shows the Amazon forest, whose vegetation is found in eight countries of South America - Venezuela (19\%), Ecuador (47\%), Peru (47\%), Colombia (54\%), Brazil (60\%), Bolivia (59\%), Suriname (87\%), and Guyana (100\%). In Brazil, the 'Amazônia Legal' (Legal 
Amazon) covers approximately $60 \%$ of the territory (it comprises the states of Amazonas, Acre, Amapá, western Maranhão, Mato Grosso, Rondônia, Pará, Roraima, and Tocantins). The Amazon Basin is one of the rainiest places on earth, with a rainfall index of up to 10 thousand millimetres in some regions, which makes it the largest area of flooded forest on the planet. The Amazon River ${ }^{2}$ is undoubtedly one of the most sumptuous elements. Pereira et al (2006) describe it as follows: it has a mean width of $12 \mathrm{~km}$, reaching more than $60 \mathrm{~km}$ during the rainy season, and the flooded areas affected by the Amazon River water network form a flood plain that is much larger than many European countries together.

The layout of the Amazon forest (Figure 1) exposes at least one fundamental - and even primary - question to be the object of a regional approach: borders, and with them, defence. Issues related to the economic exploration of the Amazon have become increasingly complex.

\section{Figure 1 - The Amazon Forest}

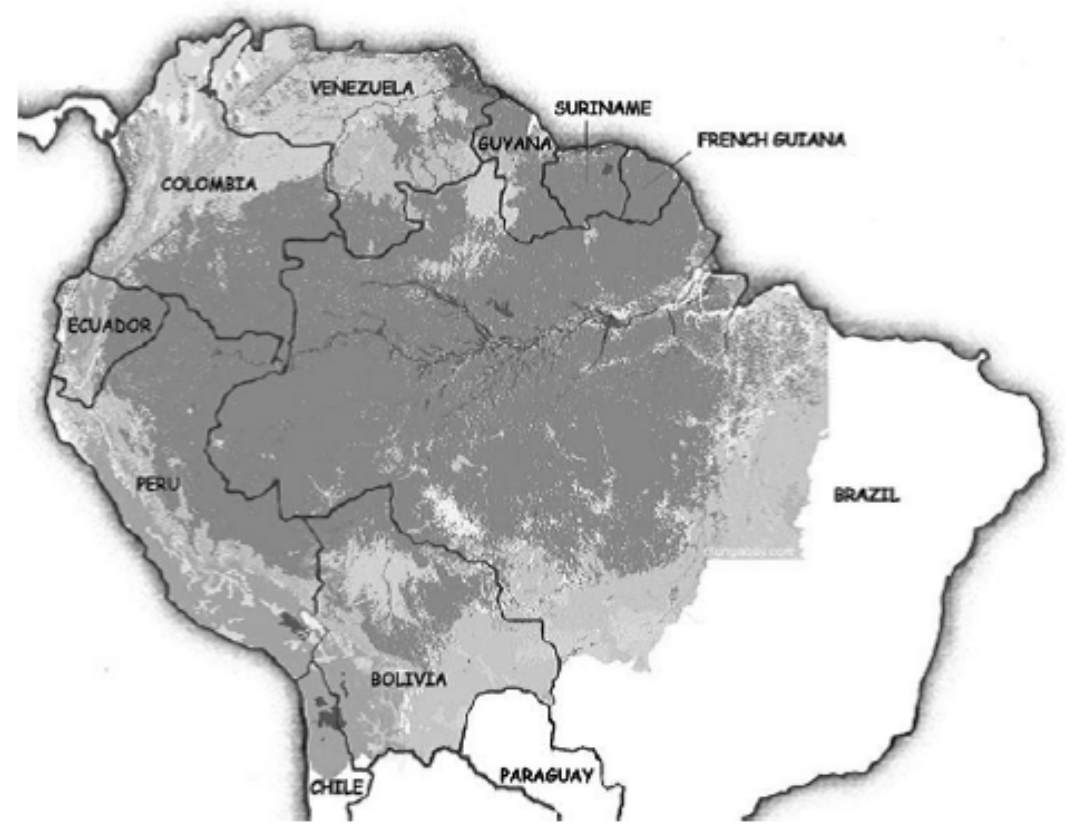

Source: Nobre (2014).

Contemporarily, in spite of an exploration based on family subsistence that occurs at some points, more intensive mining and agribusiness activities have advanced into the forest. Heredia, Palmeira and Leite (2010) highlight the expansion of the agricultural frontier in Brazil towards the Amazon, especially for soya bean production, as one of the substantial social and environmental changes brought by agribusiness. Illegal logging is one of the phenomena that has accompanied the expansion of the agricultural frontier and which has advanced in other countries, such as Colombia (Nobre 2014). The logistic branch of 'Arco Norte' (Northern Arc), where waterways and airports are planned to be 
built in Brazilian states in the Amazon, is evidence of the expansion of the soya bean complex in the Amazon. These infrastructure projects for soya bean outflow in Brazil were included in the 'Diretrizes de Política Nacional de Transporte Hidroviário' (2010) (National Water Transport Policy Guidelines) and in the 'Plano Hidroviário Estratégico' (Strategic Waterway Plan (PHE)), following superficial estimates of their socio-environmental impact, as Moreno (2015) points out.

In regards to mineral exploration, some aspects should be highlighted: (i) metallic and precious ore: gold in Pará, Amazonas, Roraima and Amapá (Brazil), and near the Malinowski River (Peru); iron in Pará, Amazonas, and Amapá (Brazil); rock salt in Amazonas and Pará (Brazil); bauxite in Pará (Brazil), as well as limestone, cassiterite, lignite, gypsum, copper, tin, lead, kaolin, diamond and nickel (Figure 2).

Figure 2 - Main Amazonian Provinces and Mineral Resources

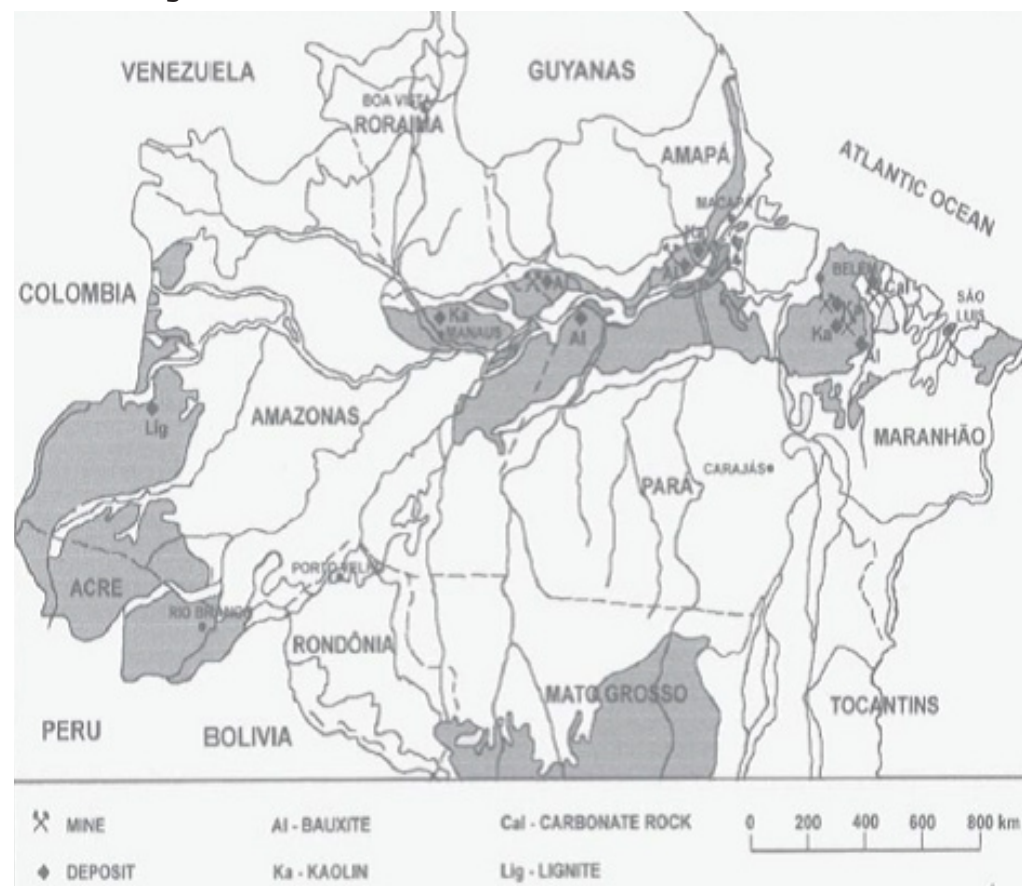

Source: Santos (2002).

The considerable bauxite deposits are concentrated in three districts, namely: Trombetas, Almeirim and Paragominas-Tiracambú, which hold the third largest bauxite potential in the world, after Australia and Guinea. There are also deposits whose exploration has a high cost, such as lignite, shared by Brazil and Colombia. In Brazil, the Tucuruí Hydroelectric Plant inaugurated in 1984 was built, as Santos (2002) explains, to supply the water demand from aluminium production complexes of companies near Belém (Pará) and São Luís (Maranhão), just as deposits of kaolin ${ }^{3}$ are used by the cellulose and paper industry. On the Brazilian side, a study carried out by the 'Companhia de Pesquisa de Recursos Minerais' (Mineral Resources Research Company (CPRM)) in 2002, using the 
Geographic Information System, indicates the existence of reserves of precious metals, aluminium, ferrous metals, gems, energy resources and industrial minerals. The agribusiness activity is located in the Brazilian states that have a border with Peru and Bolivia, and in Pará, in the so-called Legal Amazon.

Table 2 shows a list of some co-operation initiatives among countries concerning the Amazon. The 'Iniciativa para Integração da Infraestrutura Regional' (Regional Infrastructure Integration Initiative (IIRSA-Cosiplan)) has the main objective of overcoming the infrastructure bottlenecks in South America. Four axes of integration and development were delineated in the Amazon, which basically aim to commercially and productively link the Amazonian territories to the rest of the continent, and to international trade flows. In addition to these common initiatives, Brazil maintains the 'Sistema de Proteção da Amazônia' (Amazonian Protection System (Sipam)) to integrate information and generate knowledge about the Legal Amazon, and the 'Sistema Integrado de Monitoramento de Fronteiras' (Integrated Border Monitoring System (Sisfron)). Its primary objective is to strengthen the presence of the state in the border area via sensing.

The Amazon is recognised as the most biodiverse region in the world, besides being rich in iron ore, natural gas, wood, and energy resources (Castro 2010). On the other hand, its occupation processes occurred regardless of economic planning and development initiatives. Despite some initiatives to exercise state control over the Amazon (e.g. Brazil with the Superintendence for the Development of Amazonia (SUDAM)), the quality of life of a large part of the population did not experience significant positive variations (Superti 2011). These initiatives have led either to competitively inserting the Amazon in international trade trajectories or to fostering productive articulations, such as the Manaus Free Trade Zone, in Brazil.

As for the energy resources, economic differences among the Amazonian countries pose challenges to the implementation of efficient energy systems. More recently, investments to harness the energy potential of the world's largest river basin have been announced and some of them are being implemented. In IIRSA-Cosiplan, for example, the four Integration and Development Hubs (EIDs, according to the acronym in Portuguese) covering the South American Amazon (Andean, Guiana Shield, Peru-Bolivia-Brazil and Amazonas) have a total portfolio of 21 energy projects (3.6\% of the total portfolio of IIRSA-Cosiplan), eight of which have been finalised (e.g. electric interconnection project between Colombia and Ecuador, transmission line of $500 \mathrm{kV}$ from Tucuruí to Manaus) and the rest is in execution, pre-execution or under analysis. The recent construction of large hydroelectric dams in the Amazon River Basin started in the context of economic growth in the countries, especially Brazil. As mentioned in Little (2013), a total of 151 proposals for the construction of hydroelectric dams were identified in the Andean countries, and most of them (81) are in the Marñon River basin. Some emblematic cases can be cited, such as the construction of Belo Monte in the Xingu river (11233 MW capacity), which had massive and significant BNDES (Brazilian Development Bank) funding to the Norte Energia consortium. In January 2017, Belo Monte had ten turbines in operation and 2677 MW of installed capacity. In addition to Belo Monte, Little (2013) mentions the Guri hy- 
droelectric plants on the Caroní River in Venezuela, with a capacity of $10325 \mathrm{MW}$, and Jirau, on the Madeira River in Brazil, with a capacity of 3450 MW, among others.

Table 2 - Formal co-operation initiatives among Amazonian countries (2016)

\begin{tabular}{|c|c|c|c|c|}
\hline $\begin{array}{l}\text { Treaty/ } \\
\text { Agreement }\end{array}$ & Formulation & Objective & Instruments & Key measures \\
\hline $\begin{array}{l}\text { IIRSA- } \\
\text { Cosiplan }\end{array}$ & 2000 & $\begin{array}{l}\text { Infrastructure projects } \\
\text { in the region based on } \\
\text { territorial and economic } \\
\text { development links. }\end{array}$ & $\begin{array}{l}\text { Integration and } \\
\text { Development Hubs: } \\
\text { Guiana Shield, } \\
\text { Andean Hub, } \\
\text { Amazonas Hub, } \\
\text { Peru-Bolivia-Brazil } \\
\text { Hub. }\end{array}$ & $\begin{array}{l}\text { Until 2016, } 182 \text { projects } \\
\text { were considered in the } \\
\text { portfolio. Of these, } 53 \\
\text { were completed, } 54 \text { are in } \\
\text { execution and } 44 \text { under } \\
\text { analysis. }\end{array}$ \\
\hline $\begin{array}{l}\text { Amazon } \\
\text { Cooperation } \\
\text { Treaty (ACT) }\end{array}$ & 1978 & $\begin{array}{l}\text { Promote the harmonious } \\
\text { development of } \\
\text { the region and the } \\
\text { well-being of the } \\
\text { populations, besides } \\
\text { strengthening the } \\
\text { sovereignty of the } \\
\text { countries over their } \\
\text { Amazonian territories. }\end{array}$ & $\begin{array}{l}\text { Regional co-ope- } \\
\text { ration. }\end{array}$ & - \\
\hline $\begin{array}{l}\text { Amazon } \\
\text { Cooperation } \\
\text { Treaty } \\
\text { Organization } \\
\text { (ACTO) }\end{array}$ & 2002 & $\begin{array}{l}\text { It becomes an } \\
\text { international } \\
\text { organisation with a } \\
\text { permanent secretariat } \\
\text { and its own budget. }\end{array}$ & $\begin{array}{l}\text { An administrative } \\
\text { structure initiated } \\
\text { by the Meeting of } \\
\text { Ministers of Foreign } \\
\text { Affairs, Amazon } \\
\text { Cooperation Council } \\
\text { (CCA). }\end{array}$ & $\begin{array}{l}\text { More than } 10 \\
\text { initiatives, projects and } \\
\text { programmes, on the } \\
\text { environment, indigenous } \\
\text { affairs, science and } \\
\text { technology, health, } \\
\text { tourism and social } \\
\text { inclusion. }\end{array}$ \\
\hline $\begin{array}{l}\text { Northern } \\
\text { Arc }\end{array}$ & 2008 & $\begin{array}{l}\text { It has two branches and } \\
\text { comprises the Brazilian } \\
\text { states of Rondônia, } \\
\text { Amazonas, Amapá and } \\
\text { Maranhão. An initiative } \\
\text { still under study, } \\
\text { conducted by Eletrobras }{ }^{4} \\
\text { to enable energy } \\
\text { integration between } \\
\text { Brazil and the Guiana } \\
\text { Island. And another, in } \\
\text { continuous expansion, } \\
\text { agribusiness logistics. } \\
\text { This logistics branch is } \\
\text { a complex of port and } \\
\text { waterway investments } \\
\text { on the rivers Madeira, } \\
\text { Amazonas and Tapajós } \\
\text { Basin. }\end{array}$ & $\begin{array}{l}\text { Basically via } \\
\text { Eletrobras and } \\
\text { three other large } \\
\text { energy companies } \\
\text { with a Transmission } \\
\text { Hub idealised from } \\
\text { Manaus, Brazil, } \\
\text { going through the } \\
\text { French Guiana, } \\
\text { Suriname and } \\
\text { Guyana, arriving in } \\
\text { Boa Vista, Brazil. } \\
\text { In its logistics } \\
\text { aspect, it is an } \\
\text { export route. }\end{array}$ & $\begin{array}{l}\text { During Rio }+20 \text {, in } 2012 \text {, } \\
\text { the main objectives of } \\
\text { the Northern Arc were } \\
\text { discussed with the IDB, } \\
\text { and then memorandums } \\
\text { of understanding were } \\
\text { prepared. } \\
\text { In March 2013, Eletrobras } \\
\text { and the other companies, } \\
\text { the Agence Française de } \\
\text { Développement (AFD) } \\
\text { and the IDB signed the } \\
\text { Northern Arc agreement. } \\
\text { That same year, the IDB } \\
\text { released US\$1.9m. } \\
\text { In 2003, Cargill } \\
\text { company's boarding } \\
\text { terminal in Santarém was } \\
\text { inaugurated. }\end{array}$ \\
\hline
\end{tabular}

Source: Created by the authors.

Investing in infrastructure is tantamount to laying the foundations for private and public investment in economic activities, such as mining and agribusiness. The aforementioned increase in the number of projects in the Amazonian Hub of IIRSA-Cosiplan is a consequence of the increase in the investments of Brazilian and Chinese companies in 
Amazonian countries, among others. There are bilateral agreements between these countries for investments in infrastructure, such as the Northern Arc and the Peru-Brazil Energy Agreement. On the other hand, technical and economic co-ordination between the governments of these countries for the conservation of the Amazon biome is more complex. As described by Little (2013), the South Interoceanic highway inaugurated in 2011 crosses the triple border, or more precisely, Puerto Maldonado, Cobija and Rio Branco, and has $5404 \mathrm{~km}$ of extension. The lack of planning of social and environmental impacts, for instance, has facilitated the illegal exploration of gold in Madre de Dios, Peru, and the growth of human and drug trafficking between Peru, Bolivia and Brazil. However, the governments of these countries have not determined an effective and co-ordinated solution to these impacts.

The inclusion of the Amazon in national policies or regional co-operation agreements has always been associated with the possibility of exploration of natural resources, including its harmful effects. ${ }^{5}$ During developmentalism, Brazil had in the Amazon a safe harbour for vegetable and mineral extractivism, and for infrastructure projects, such as the construction of the Trans-Amazonian Highway in the 1970s. The TCA listed in Table 2 is also an example of that plan. In the 2000s, abundant natural resources and investment opportunities gave rise to the organisation of an axis called the Northern Arc, which covers the Madeira and Amazon River valleys.

The first investments in the Amazon were carried out in the 1960s by multinational companies motivated by a strategic understanding of resources, that is, to look for alternative supplies to meet the expected growth of the consumer market, and to prevent a shortage of resources. Santos (2002) reports that the first investments were aimed at aluminium and manganese prospection, both needed according to the technological metal mechanical paradigm at the time. With the first oil price shock in 1973, the international prices of mineral commodities such as aluminium and manganese had a steep decline, and others like gold experienced a considerable increase. This fact, along with the then initiated displacement of mining companies from developed countries, stimulated the mining activity in the Amazon, especially in its Brazilian portion.

In the 1970s and 1980s, the region experienced an unprecedented advance in gold exploration, stimulated by economic and political factors, and especially by the increase in the international prices of this commodity (Cleary 1990, cited in Nobre 2014). Mining and agribusiness (grains and livestock) are basically performed in this region, considering the size of the Amazon in relation to the South American territory (Figure 1). On the other hand, these activities have advanced without planning and in a diffuse way.

The notion that the economic use of mineral resources goes against economic development has been increasingly reconsidered in the light of recent cases, such as South Africa and Ghana (Figueiredo and Piana 2016). That is, the economic exploration of Amazonian mineral resources requires a state strategy that includes and encourages business investment through the establishment of learning partnerships. After the boom of the commodity prices, academic studies attempted to evaluate the occurrence of a possible reprimarisation of the export agenda in the region, and the weight of natural resource- 
intensive sectors in these countries' structural change (economic development). Rocha (2015) relativises the argument that the effects of chaining of primary activities are weak. He considers that the natural resource export sector has a higher productivity than the domestic market one. Natural resource exports have positive spillover effects for the domestic sector, and productivity and chaining are as strong as in manufacturing.

That is, the Amazon and economic exploration of natural resources can turn out to be a (sustainable) economic development strategy. In the first years of the $21^{\text {st }}$ century, the Amazon should be considered as part of the dynamics of capital appreciation at the national and international levels. The expansion of Chinese companies' investment in this region, which will be discussed in the next section, is evidence of that. Brazil, which is the largest South American economy, has also funded the internationalisation of large companies through the BNDES, in activities related to natural resources and infrastructure (construction, meat processing and mining companies). However, as Moreno (2015), Little (2013), and González-Vicente (2012) argue, investment projects have been taking place without adequate impact studies, and are mainly geared towards international capital, fostering export corridors.

Within the institutional framework of the United States Agency for Development and Cooperation (USAID) is the Andean Amazon Conservation Initiative (ICAA), whose first phase took place between 2006 and 2011, and the second phase between 2011 and 2016 . The Andean countries - Ecuador, Colombia, Bolivia and Peru - are beneficiaries of this US initiative, which through technical and financial assistance intends to contribute to the conservation of the Amazonian biome. Consortiums are being arranged with nongovernmental organisations, research institutes and universities in these countries and the United States (e.g. Rainforest Alliance, Fundación Natura, Fondo de las Américas del Perú, Coordinadora de Organizaciones Indígenas de la Cuenca Amazónica, among others). In spite of its undeniable contribution to articulating different actors for the conservation of the Amazonian biome, it is a relevant question if the presence of the USA may reinforce the fragmentation of the South American countries regarding the political strategy for the Amazon.

The points highlighted in this section were discussed between China and Latin American countries within the framework of the China-CELAC Forum (Community of Latin American and Caribbean States). The Cooperation Plan (2015-2019), for example, sets out a common understanding and joint actions on policy and security, improving representation in international forums, promoting trade and investment, and fostering infrastructure and co-operation on energy and natural resources (e.g. research and development of technology on the sustainable use of resources). There are also actions planned for the industry and for science and technology (e.g. study on the joint construction of industrial and science and technology parks). The size of the investment of Chinese companies in the Amazon deserves analysis attention as to the way they are distributed, both in sectors and geographically, and the effects of productive and environmental chaining they may produce, especially considering that the articulation and technical, political and economic co-ordination among Amazonian countries is minimal and has evolved very little, as Table 1, analysed in this subsection, suggests. 


\section{Investments of Chinese companies in the Amazon: analysis and perspectives}

The emergence of China as an economic power has led to changes in production structures, especially in developing countries. By consolidating its industrialisation, the country induced an expansion of the industries related to natural resources globally. The debate on a possible reconfiguration of the international division of labour promoted by China is ongoing and was not detailed in this article because of its complexity. However, it is worth considering that the expansion of the Chinese presence in the Amazon is a consequence of this order of facts, as pointed out in Table 1. The increase in the volume of Chinese direct investment in the continent is described by Ellis (2012) in three main moments: (i) pre-2002, distant relationship focused on political issues, such as the South-South ties; (ii) simple trade expansion between 2002 and 2007, when China entered the World Trade Organization (WTO); and (iii) post-2007, when China became a major FDI player, especially in developing countries.

The state and the Communist Party of China are central forces of the production and consumption model, and therefore, of China's economic growth. Political power remains concentrated, although the economic and geopolitical changes cause transformations in the scope of operation of the Chinese state enterprises (SOEs). That is to say, if it is not always possible to determine the extent of Chinese FDI in economic development projects of developing host countries, it is not wrong to assume that Chinese companies have the guidelines of their negotiation with the public sectors of those countries very well defined. González-Vicente (2012: 48), on the discussion of the interests of Chinese companies in developing countries, identifies the business pragmatism within these companies: 'Chinese investors are attracted to areas where other Chinese companies operate and where they can share knowledge and networks that could facilitate the adaptation to new settings.'

From this perspective, it can be observed that the Chinese investments announced since 2010 are from oil companies, such as China National Petroleum Corporation (CNPC); agricultural, fishery and mining industries, such as Chongqing Grain, BBCA, China Fishery and China Nonferrous; in the automotive sector, such as EFFA, Shaanxi Automobile Group, Foton Motors, Changan International Corporation, Foton Lovol Bramax, among others; and in infrastructure, besides the transoceanic railroad between Brazil and Peru; in addition electricity companies such as State Grid are present in this region (Table 3).

The debate over the impacts of the Chinese presence on the economic development of these countries, and of Latin America and the Caribbean in general is set as discussed in the previous subsection of this article, in terms of outflow and inputs. Logistical facilities such as electricity have been incorporated in joint initiatives between the countries, such as IIRSA-Cosiplan and mixed ones, such as the Northern Arc. This occurs in the same way as the investments of Chinese companies associated with these initiatives in infrastructure and activities of use of natural resources (Table 3). The governments of Brazil, Peru, Ecuador, Colombia and other countries in the region consider China as a partner in their economic development.

The strategy of productive internationalisation of the Chinese companies has occurred mainly in the joint venture model (Andreff 2016). Thus, companies do not take all 
the risks inherent to local production in another country, but rather associate with companies that are already installed, generally acquiring a majority shareholding. This model of productive internationalisation is a co-operative business activity whereby two companies create an independent business (Punnet and Shenkar 1996). Dunning, Kim and Park (2008) emphasise that multinational companies of developing countries seek to broaden their competencies and not to maintain full control of new (greenfield) projects as they used to. Acquiring shares of companies in the host country (joint venture) helps accelerate the process of tacit knowledge. Internationalisation by joint venture was a learning mechanism of western management style for the Chinese state-owned enterprises, and for their operational and technological development (Salidjanova 2011). However, the joint venture model is full of challenges regarding management itself (Meyer and Estrin 2006).

Table 3 - Description of investments of Chinese companies in the South American Amazon

\begin{tabular}{|c|c|c|c|}
\hline Company & Ownership & Segment / Sector & Investment models \\
\hline $\begin{array}{l}\text { China National } \\
\text { Petroleum } \\
\text { Corporation (CNPC) }\end{array}$ & $\begin{array}{l}\text { State- } \\
\text { owned }\end{array}$ & $\begin{array}{l}\text { Upstream activities in the oil } \\
\text { chain. }\end{array}$ & $\begin{array}{l}\text { Interest of } 10 \% \text { as an operator in } \\
\text { the pre-salt Libra field in Brazil. }\end{array}$ \\
\hline $\begin{array}{l}\text { China Fishery } \\
\text { Group Limited }\end{array}$ & Holding & $\begin{array}{l}\text { Fishery and commercialisation } \\
\text { of fish. }\end{array}$ & $\begin{array}{l}\text { Interest (over } 50 \% \text { ) in the } \\
\text { Norwegian company Copeinca } \\
\text { ASA, which operates in fishery } \\
\text { exploration in Peru. }\end{array}$ \\
\hline $\begin{array}{l}\text { Chongqing Grain } \\
\text { Group Co }\end{array}$ & $\begin{array}{l}\text { State- } \\
\text { owned }\end{array}$ & $\begin{array}{l}\text { Production of biofuel and soya } \\
\text { goods. }\end{array}$ & $\begin{array}{l}\text { In Brazil, it announced an } \\
\text { investment in the construction of a } \\
\text { soya bean processing plant in the } \\
\text { west of the state of Bahia, but the } \\
\text { project is interrupted. }\end{array}$ \\
\hline Hunan Dakang & Private & $\begin{array}{l}\text { Production and distribution of } \\
\text { dairy products. Production and } \\
\text { distribution of pork and mutton. }\end{array}$ & $\begin{array}{l}\text { The firm and its parent company, } \\
\text { Pengxint, agreed to buy an interest } \\
\text { (around } 57 \% \text { ) in Fiagril, a Brazilian } \\
\text { grain processing and trading } \\
\text { company located in Mato Grosso. }\end{array}$ \\
\hline BBCA Brazil & $\begin{array}{l}\text { State- } \\
\text { owned }\end{array}$ & $\begin{array}{l}\text { Chemical industry, holding } 20 \% \\
\text { of the international citric acid } \\
\text { market. }\end{array}$ & $\begin{array}{l}\text { Under construction in the Brazilian } \\
\text { state of Mato Grosso do Sul. It will } \\
\text { be a chemical industrial plant based } \\
\text { on the processing of maize and } \\
\text { cogeneration of energy. }\end{array}$ \\
\hline $\begin{array}{l}\text { State Grid Brazil } \\
\text { Holding }\end{array}$ & $\begin{array}{l}\text { State- } \\
\text { owned }\end{array}$ & Power transmission. & $\begin{array}{l}\text { Acquisition of seven national power } \\
\text { transmission companies in Brazil. }\end{array}$ \\
\hline $\begin{array}{l}\text { China Three } \\
\text { Gorges } \\
\text { Corporation }\end{array}$ & $\begin{array}{l}\text { State- } \\
\text { owned }\end{array}$ & Power transmission. & $\begin{array}{l}\text { Acquisition of interest in } \\
\text { consortiums of hydroelectric plants } \\
\text { along the Amazon River Basin. }\end{array}$ \\
\hline Shineray & $\begin{array}{l}\text { State- } \\
\text { owned }\end{array}$ & Automotive. & $\begin{array}{l}\text { Importation of Chinese motorcycles, } \\
\text { cars and bicycles to the Brazilian } \\
\text { market. }\end{array}$ \\
\hline $\begin{array}{l}\text { Shaanxi } \\
\text { Automobile Group } \\
\text { (SAG) }\end{array}$ & $\begin{array}{l}\text { State- } \\
\text { owned }\end{array}$ & $\begin{array}{l}\text { It designs, produces and exports } \\
\text { heavy trucks (from China), dump } \\
\text { trucks for concrete, among others. }\end{array}$ & $\begin{array}{l}\text { It manufactures Shacman trucks in } \\
\text { the Brazilian state of Pernambuco. }\end{array}$ \\
\hline
\end{tabular}

*Note: Based on information from Bloomberg and Financial Times websites. 
Considering the Amazonian perspective on natural resources, and the exit to the $\mathrm{Pa}$ cific Ocean through countries such as Peru, the aforementioned investments are described below separated by sector.

\section{Mining and steel industry}

The first Chinese company invested in Peru during the 1990s, when mining was privatised. The Chinese state-owned company Shougang bought Hierro Peru in 1992, as soon as the privatisation programme began. In the 2000s, state-owned Chinalco (Aluminium Corporation of China) acquired Peru Copper in 2006, and the right to explore the Toromocho mine in Peru for US\$790m. Chinalco also announced a joint venture with the Peruvian company Centromin. In 2007, two Chinese state-owned enterprises, Minmetals and Jiangxi Copper, formed the consortium Minmetals Jiangxi Copper Mining Investment Co., Ltd. by which they acquired Monterrico Metals and, thus, the Rio Branco project. In 2010, the Chinese company Minmetals acquired a majority shareholding in Northern Peru Copper via joint venture, coming to control the El Galeno copper and gold mines and the Hilorico gold mine in northern Peru, investing US $\$ 2.5 b$ (The Heritage Foundation 2014). Chinalco aims to become a primary aluminium producer in China, and is the sole producer of aluminium oxide (alumina).

Finally, MMG Limited, a subsidiary of Minmetals Corporation, has announced a consortium formed by MMG, Guoxin International Investment Corporation Ltd. - or just Guoxin International - and CITIC Metal Co., Ltd. and signed an egalitarian acquisition agreement for the Las Bambas copper mine with Glencore Xstrata of Peru, worth US\$5.85b. In 2016, Minmetals announced that the Las Bambas copper mine would start its operation with a daily production capacity of more than 400000 tonnes of copper (China Minmetals Corporation 2016).

Among other transactions involving Peruvian mining companies, the Chinese government's sovereign wealth fund, the China Investment Corporation (CIC), ${ }^{6}$ made a US $\$ 651.7 \mathrm{~m}$ investment in the Brazilian company Vale, as reported by the Securities and Exchange Commission fund (SEC) of China (Exame.com 2010). The interest of this fund in Vale is one of the most significant. In 2016, however, this investment was the base for the CIC to negotiate an early purchase of iron ore with Vale (Época Negócios Magazine 2016), so that the fund would profit from a slight recovery of mineral commodity prices, without having to bear the operating costs of the mines.

In 2010, the semi-state company East China Mineral Exploration and Development Bureau (Jiangsu) agreed with the Brazilian company Itaminas Comércio de Minérios S.A. to acquire it and its operations in the east of Minas Gerais. Itaminas reserves were around $1.3 \mathrm{~b}$ tonnes of iron ore at the time, with the advantage that the ore could be shipped directly through the port of Rio de Janeiro. This kind of investment did not overlap with the Chinese purchases of Brazilian iron ore, which in 2001 totalled $20.3 \mathrm{~m}$ tonnes exported to China, and in 2007 it more than tripled, reaching 89m tonnes. However, the acquisition of Itaminas' operations by East China is much more strategic for China, to ensure the outflow of this raw material at a lower cost. That is because the transaction was followed by 
an infrastructure project connecting Minas Gerais to Rio de Janeiro, thus facilitating the outflow of iron ore to the Asian country.

In 2011, CITIC Group, Baosteel Group Corporation, Anshan Iron \& Steel Group Corporation, Shougang Corporation and Taiyuan Iron \& Steel Group Co., Ltd. formed a consortium named China Niobium Investment Holdings Ltd., and acquired 15\% of the Companhia Brasileira de Metalurgia e Mineração (CBMM) for about US\$1.95b. Brazil has the largest niobium reserve in the world, but there is not a national plan for its exploration, which is more complex than the exploration of iron ore.

\section{Oil and energy}

In regards to the oil sector, CNPC and Sinopec acquired assets of the Ecuadorian subsidiary of the Canadian oil company in 2005, for approximately US $\$ 1.4 \mathrm{~b}$, through the consortium Andes Petroleum. In 2006, Sinopec bought from Colombia 50\% of the shares in the US firm Omimex. In 2013, PetroChina acquired the assets of Petrobras in Peru in a transaction of US\$2.6b. The entry of Chinese companies into the Brazilian oil market began in 2005, when Sinopec offered engineering services to Engineering Procurement and Construction (EPC), and participated in the construction of part of the Gasene project - a gas pipeline linking the pipeline network of the Southeast and Northeast regions. In 2009, Sinopec signed an oil purchase agreement with Petrobras for 10 years, as the guarantee for a US\$10b loan from the China Development Bank to this Brazilian company. In 2013, CNOOC and CNPC acquired a 10\% interest each in the winning consortium in the auction of the Libra field, whose reserves are estimated between 8 and 12 billion $\mathrm{BOE}^{7}$ (Almeida and Consoli 2014).

In 2010, State Grid announced an investment of approximately US\$990m in the company Plena Transmissoras, in Brazil. Its presence in the Brazilian electricity sector has expanded considerably since then. In 2015, it was the winner, with a $51 \%$ interest in a consortium with Eletronorte (24.5\%) and Furnas (24.5\%), in the auction for the construction of the line that distributes energy from the Belo Monte plant. In 2017, Chinese companies such as State Grid and China Three Gorges (CTG) expressed their interest in acquiring Belo Monte, reinforcing the significant and massive presence of Chinese companies in the Brazilian electricity sector. The Chinese company CTG is present in other major hydroelectric plant projects along the Amazon River Basin. In 2016, an agreement was reached between CTG and the Brazilian company Furnas, controlled by Eletrobras, for the construction and operation of the São Luiz do Tapajós hydroelectric plant (UHE Tapajós) in Pará. Since 2014, CTG and Furnas have also been partners in a consortium for the construction of the São Manoel hydroelectric plant (HPP São Manoel), with 700MW, on the Teles Pires River, also in Pará. However, in 2016, the Brazilian Institute of Environment and Renewable Natural Resources (IBAMA) cancelled the Tapajós hydroelectric plant licensing process, while the São Manoel hydroelectric plant was almost finished by the end of 2016 and is expected to start operating before 2018.

In the same year, Sinopec invested US\$7.1b in Repsol do Brasil. This investment will enable Repsol do Brasil to fully develop all of its current projects, which include one of the largest exploration projects in the recent period. Along with CNPC, Sinopec invested 
US\$610m in an unknown company in Ecuador. In 2011, a US\$4.8b investment in Galp Energia from Brazil was announced, also by Sinopec. Together, CNOOC and CNPC invested US\$1.2b in Petrobras, Shell and Total in 2013.

\section{Fishery and grains (agribusiness)}

The fishery industry has been the object of growing interest for Chinese investments. In 2013, the Chinese state-owned enterprise China Fishery Group (Reed 2013) became the controlling shareholder of the Norwegian company Copeinca ASA, which operates in Peru, in a US\$555.8m transaction (Fairlie 2014). Throughout the 1990s and the 2000s, Peru reformulated its fishery law by enacting a law in 1997 to determine the rights of sustainable use of natural resources, arriving at the system of individual quotas established in 2009, which greatly benefited Copeinca. China Fishery Group is a global industrial fishing company, controlled by Pacific Andes International Holdings Ltd. since 1986. ${ }^{8}$ It operates throughout the fishery production chain and ensures for itself the ability to continuously access natural resources. However, in 2016, China Fishery Group announced the sale of its assets in Peru to avoid its bankruptcy on the New York Stock Exchange. It is estimated that the total debt of its companies in Peru reaches US\$883m (Semanaeconómica 2016). In principle, the explanation for the decision to sell its assets also seemed to be related to the low anchovy ${ }^{9}$ fishing quota granted to China Fishery for the second season of 2015, and the uncertainties about the quota for the following season.

In Brazil, although the purchase of Brazilian land by foreigners was limited in 2009 by the Attorney General of the Union, ${ }^{10}$ Chinese companies have been building factories in the Brazilian Midwest - near the area where the transoceanic highway will be (see section 3). That is the case for BBCA, one of the companies owned by COFCO (Table 2). After projections began in 2013/14, BBCA initiated the construction of a maize processing plant in 2016, in the municipality of Maracaju, in the Brazilian state of Mato Grosso do Sul. The construction was the result of an agreement signed by the state governor, the municipality mayor and the executive of the BBCA (O Correio News 2016). In 2016, the Chinese state gave stronger signals of its strategy of controlling the links of grain production in order to counterbalance the concentration exerted by the four large grain multinationals: ${ }^{11}$ part of the Brazilian trading Fiagril, located in Mato Grosso, which is in the Legal Amazon. Therefore, it was acquired for US $\$ 200 \mathrm{~m}$ by the state-owned Hunan Dakang International Food \& Agriculture Co., Ltd. of the Shanghai Pengxin business conglomerate (Valor Econômico 2016).

Wilkinson, Wesz Junior and Lopane (2016) consider that the relationship of the Chinese state with the agribusiness sector in Brazil, as materialised in state-owned enterprises, is a strategic mechanism for the Asian state to control the grain production chain, such as for soya beans. Oliveira (2015) lists several Chinese grain and agro-industrial companies in general operating in Brazil and the Southern Cone. China National Cereals, Oils and Foodstuffs Co. (COFCO) is a state-owned company of the national government of China that initially acquired interests in Nidera, the largest trading company in the Netherlands, and the agro-industrial arm of Noble Group. Most recently, it has taken $100 \%$ control of 
Nidera, ${ }^{12}$ expanding its operations in Brazilian agribusiness. ${ }^{13}$ Nidera and Noble have assets in Brazil, Argentina, Australia and the Black Sea.

The analysis in this article of the direct investment expansion of Chinese companies closed in 2014 to maintain the correspondence with the time period of the data presented in Table 1 (for Chinese FDI evolution in Latin America), as well as because, from 2014, a new configuration of these investments can be observed. The preponderance of sectors such as electricity in Brazil is mainly one of these aspects.

\section{Final considerations}

The main objective of this article is to seek to systematise conceptions of the Chinese presence in countries of the Amazon, describing China's main movements in terms of investments of companies from the Asian country. The Amazon was treated as a whole. It still has an investment position of Chinese companies in some countries, such as Brazil, Peru and, to a lesser extent, Colombia and Ecuador.

The article focused on two main sections. Following the introduction, the second section consisted of a review of the literature on the expansion of investments of Chinese state-owned enterprises in developing countries in particular, and their implications for economic development. The theme of this section was to systematise the conceptions about this phenomenon and to point out the multinational Chinese companies as business actors that can follow strategies elaborated under the five-year plans of the State Council of China, as well as the regulations established by the host countries of their investments.

In the third section, we sought to locate the Amazon in the economic and political context of South America and highlight the presence of Chinese companies, in addition to characterising the Amazon as to the natural resources and initiatives existing between the governments of the Amazonian countries for technical and economic co-operation. In spite of the attention to the fundamental socio-environmental issues, the expansion of investments of large multinational companies (in the case of this article, Chinese) exposes the Amazon to economic factors that could be treated in a co-operative way among the countries. The second part of this section sought to describe and characterise the advance of Chinese companies in natural resources in Amazonian countries. Despite some common measures among the governments of these countries (see Table 1) there is no systematic treatment for this phenomenon. At the same time the Chinese companies were adopting a model of internationalisation by joint venture to improve their management techniques, without needing to be directly involved with the domestic issues of the host countries. In fact, in this subsection, Brazil received a larger space for analysis. As pointed out in the second section (see Table 1), it is the country that has received the most investments from Chinese companies. In addition, the construction of the Interoceanic highway or Road of the Pacific covers much of the Brazilian territory, as will the (foreseen) transcontinental railroad. On the other hand, it is clear that taking the Amazon and not only Brazil or Brazil and Peru is justified by the geo-economic complexity of this region. The expansion of investments in these countries certainly affects the region as a whole. 
In this perspective, the plans to build a railroad that connects Brazil to the Pacific, from the Southeast Region through Amazonian territories, brought the perspective of a new phase of Chinese investments in South America. Unfortunately, these countries do not maintain an articulated plan for the research and prospecting of their mineral resources, or for their exploration. At the same time, the investments of Chinese companies have been structured alongside mega infrastructure projects. That is, as in other host developing countries, when Chinese companies invest, they also rely on the Chinese state's support for logistics and infrastructure. At the same time, despite physical integration plans such as IIRSA-Cosiplan, the South American countries (the Amazon, in the case of this study) remain passive in the reception of these investments. Even more accurate studies in terms of socio-environmental impacts are not carried out. The internationalisation pattern of Chinese companies, considering the Amazon and even more so Brazil and Peru, until 2014 was concentrated in natural resources, more so in the construction of infrastructure for this exploration.

This article consisted of a first product of the research that has been conducted regarding the Latin American insertion, especially that of South America, in the internationalisation of the great Chinese state enterprises. Its more descriptive approach was also intended to call attention to this phenomenon. A myriad of analytical developments is possible from this article. One of them, already underway, focuses on the regulatory implications of the expansion of the 'Chinese presence' in the Brazilian electricity sector.

\section{Notes}

1. Although Latin America has been the primary object of study of recent academic research on economic relations with China, we emphasised South America for two main reasons: (i) it is the geographic and influence region of Brazil, which is in fact our object of study; (ii) it is where China maintains significant investment in natural resources when compared to Latin America as a whole, such as in Venezuela, Peru, Chile and Argentina, besides Brazil. Abdenur and Souza Neto (2013) point out that the investments of Chinese companies in infrastructure in the north of South America, in countries such as Suriname and Venezuela, have been growing significantly.

2. The Amazon River starts in Peru, at the confluence of the Ucayali and Marañón rivers, it enters Brazil under the name of Solimões and, upon receiving the waters of the Negro River, located near the Brazilian city of Manaus in the state of Amazonas, is then called Amazonas.

3. For more information, we recommend Wilson, Santos and Santos (1998).

4. Authorised by Law No. 11 651, 27 of April 2008, directly or through its subsidiaries, to associate with or without the provision of funds for the formation of business consortiums and interest in partnerships in Brazil or abroad.

5. As an example, the following references can be cited in Brazil: Política de Defesa Nacional (National Defence Policy (PDN)), Programa Calha Norte (Calha Norte Programme (PCN)), Sistema de Proteção da Amazônia (Amazonian Protection System (Sipam)).

6. The China Investment Corporation (CIC) was established in 2007. It is state owned and holds at least US $\$ 200 \mathrm{~b}$ in capital provisions. Its purpose is to facilitate the diversification of Chinese direct foreign investment. Particularly CIC International, established in 2011, is tasked with managing assets of Chinese companies abroad. And it does so through financial management that seeks maximum profitability for the country's business assets (in different operations, such as stocks, hedge funds and government bonds). In addition to CIC International, CIC has two other subsidiaries: CIC Capital, established in 2015, with the objective of improving the foreign direct investment portfolio for long-term assets; and Central Huijin, 
which makes strategic investments in China's financial institutions, without intervening in the management of these organisations (China Investment Corporation 2016).

7. Barrel of oil equivalent is a unit of measure based on the approximate energy obtained when burning a barrel of crude oil.

8. In 2010, according to Fairlie (2014), the US controlling shareholder, Carlyle, increased its interest to approximately $30 \%$.

9. Source of fish meal and olive oil production, among others. Based on FAO estimates, Peru is the world's largest producer of fish meal.

10. Since 2015, there has been increasing pressure from parliament officials to reverse this measure, which limits the size of land purchased by foreigners (Daher 2015).

11. For further reading, we recommend Wesz Junior (2014).

12. COFCO is said to have incurred losses of at least US\$150m in the acquisition of Nidera due to accounting errors detected after the operation was completed (SNA 2016).

13. China's entry into the soya bean production chain has represented a transformation in the traditional pattern of grain trade. We recommend the reading of Wesz Junior (2014) and Wilkinson, Wesz Junior and Lopane (2016).

\section{References}

Abdenur, Adriana Erthal. 2013. 'A China na América Latina: Investimento em Infraestrutura Portuária.' Pontes [online] 9 (2). At https://www.ictsd.org/bridges-news/pontes/news/a-china-naamérica-latina-investimento-em-infraestrutura-portuária [Accessed on 20 November 2014].

Abdenur, Adriana Erthal and Danilo Marcondes Souza Neto. 2013. 'La Creciente Influencia de China en el Atlántico Sur. Revista CIDOB d’Afers Internacionals 102-103: 169-197.

Almeida, Edmar and Helder Consoli. 2014. 'A Entrada e os Próximos Passos dos Chineses no Setor de Petróleo no Brasil.' Infopetro [online]. 14 July. At https://infopetro.wordpress.com/2014/07/14/aentrada-e-os-proximos-passos-dos-chineses-no-setor-de-petroleo-no-brasil/ [Accessed on 20 November 2014].

Andreff, Wladimir. 2014. 'Outward Foreign Direct Investment by Brazilian and Indian Multinational Companies: Comparison with Russian-Chinese Multinationals.' In S Balashova and V Matyushok (eds), The Trajectory of Growth and Structural Transformation of the World Economy Amid International Instability. Moscow: Peoples' Friendship University of Russia, pp. 252-297.

Armony, Ariel C and Julia C Strauss. 2012. 'From Going Out (Zou Chuqu) to Arriving in (Desembarco): Constructing a New Field of Inquiry in China-Latin America Interactions.' The China Quarterly 209: 1-17.

Boisot, Max and Marshall W Meyer. 2008. 'Which Way Through the Open Door? Reflections on the Internationalization of Chinese Firms.' Management and Organization Review 4 (3): 349-365.

Bräutigam, Deborah and Tang Xiaoyang. 2012. 'Economic Statecraft in China’s New Overseas Special Economic Zones: Soft Power, Business, or Resource Security?' International Affairs 88 (4): 799 816.

Buckley, Peter J, L Jeremy Clegg, Adam R Cross, Xin Liu, Hinrich Voss and Ping Zheng. 2007. 'The Determinants of Chinese Outward Foreign Direct Investment.' Journal of International Business Studies 38 (4): 499-518. 
Carmody, Padraig and Francis Owusu. 2011. 'A Expansão da China para a África: Interesses e Estratégias.' In Rodrigo Pimentel Ferreira Leão, Eduardo Costa Pinto, Luciana Acioly (eds), A China na Nova Configuração Global: Impactos Políticos e Econômicos. Brasília: IPEA, pp. 235-267.

Chen, Taotao and Miguel Pérez Ludeña. 2014. 'Chinese Foreign Direct Investment in Latin America and the Caribbean.' CEPAL - Production Development Series 195. Santiago: CEPAL.

Cheng, Leonard Kwok-Hon and Zihui Ma. 2010. 'China's Outward Foreign Direct Investment.' In Robert C Feenstra and Shang-Jin Wei (eds), China's Growing Role in World Trade. Chicago: University of Chicago Press, pp. 545-578.

Cheung, Yin-Wong and Xingwang Qian. 2009. 'Empirics of China's Outward Direct Investment.' Pacific Economic Review 14 (3): 312-341.

China Investment Corporation [online]. 2016. At http://www.china-inv.cn/ [Accessed on 18 December 2016].

China Minmetals Corporation [online]. 2016. 'China's Largest Overseas Acquisition in Metal and Mining Industry put Into Operation.' 28 January. At http://www.minmetals.com/english/ News/201602/t20160217_187908.html [Accessed on 20 October 2016].

Comisión Económica para América Latina y el Caribe (CEPAL). 2015. América Latina y el Caribe y China: Hacia una Nueva Era de Cooperación Económica. Santiago: CEPAL.

Daher, Rui. 2015. 'Cresce a Pressão contra PL que Limita a Compra de Terras por Estrangeiros.' Carta Capital [online]. 11 September. At http://www.cartacapital.com.br/economia/cresce-a-pressao-contra-pl-que-limita-a-compra-de-terras-por-estrangeiros-1955.html [Accessed on 20 October 2016].

Dohse, Dirk Christian, Robert Hassink and Claudia Klaerding. 2012. 'Emerging Multinationals, International Knowledge Flows and Economic Geography: A Research Agenda.' KIEL Working Paper No. 1776. Kiel: Kiel Institute for the World Economy. At https://www.ifw-members.ifw-kiel.de/ publications/emerging-multinationals-international-knowledge-flows-and-economic-geographya-research-agenda [Accessed on 10 November 2016].

Dunning, John H. 2010. New Challenges for International Business Research: Back to the Future. Cheltenham: Edward Elgar.

Dunning, John H, Changsu Kim and Donghyun Park. 2008. 'Old Wines in New Bottles: A Comparison of Emerging Market TNCs Today and Developed Countries TNCs Thirty Years Ago.' SLPTMD Working Paper Series No. 11.

Ellis, R Evan. 2012. 'The United States, Latin America and China: a “Triangular Relationship.” InterAmerican Dialogue Working Paper.

Época Negócios [online]. 2016. 'Fundo Soberano da China Quer Compra Antecipada de US\$ 9bi em Minério da Vale.' 19 August. At http://epocanegocios.globo.com/Empresa/noticia/2016/08/fundo-soberano-da-china-quer-compra-antecipada-de-us-9-bi-em-minerio-da-vale.html [Accessed on 20 November 2016].

Exame.com [online]. 2010. 'Fundo Soberano Chinês tem US\$ 651,7 milhões na Vale.' 10 October. At http://exame.abril.com.br/mercados/fundo-soberano-chines-tem-us-651-7-milhoes-vale-532270/ [Accessed on 10 January 2015].

Fairlie, Alan. 2014. 'La Inversión Extranjera Directa de China en Perú. Los Casos de China Fishery Group y Chinalco.' In Enrique Dussel Peters (ed.), La Inversión Extranjera Directa de China en 
América Latina: 10 Estudios de Caso. Coyoacán: RED ALC-CHINA, UDUAL, UNAM/Cechimex, pp. 133-226.

Figueiredo, Paulo N and Janaina Piana. 2016. 'When "One Thing (Almost) Leads to Another": A Micro-Level Exploration of Learning Linkages in Brazil's Mining Industry.' Resources Policy 49: 405414.

Frischtak, Claudio, André Soares and Tania O'Conor. 2013. Chinese Investments in Brazil From 2007-2012: A Review of Recent Trends. Rio de Janeiro: China-Brazil Business Council (CBBC).

Gonzalez, Vicente R. 2012. 'Mapping Chinese mining investment in Latin America: Politics or market?’ The China Quarterly 209: 35-58.

Gonzalez, Vicente R. 2013. 'Development dynamics of Chinese resource-based investment in Peru and Ecuador.' Latin American Politics and Society 55 (1): 46-72.

Heredia, Beatriz, Moacir Palmeira and Sérgio Pereira Leite. 2010. 'Sociedade e Economia do “Agronegócio.” Revista Brasileira de Ciências Sociais 25 (74): 159-176.

Huang, Yiping and Bijun Wang. 2011. 'Chinese Outward Direct Investment: Is There a Chinese Model?' China \& World Economy 19 (4): 1-21.

Jenkins, Rhys Owen. 2011. 'The "China effect" on Commodity Prices and Latin American Export Earnings.' CEPAL Review 103: 73-87.

Karreman, Bas, Martijn J Burger and Frank G van Oort. 2016. 'Location Choices of Chinese Multinationals in Europe: The Role of Overseas Communities.' Tinbergen Institute Discussion Paper 16 (78): 1-41.

Kato, Aya. 2013. Internationalization Patterns of Chinese Companies in Emerging Markets the Case of the Construction Industry. Master's Thesis, University of Freiburg, Germany.

Kimura, Koichiro. 2013. 'Outward FDI from Developing Countries: A Case of Chinese Firms in South Africa.' Institute of Developing Economies (IDE) Discussion Paper 385: 1-13.

Kolstad, Ivar and Arne Wiig. 2011. 'Better the Devil You Know? Direct Investments in Africa.' Journal of African Business 12 (1): 31-50.

Kotschwar, Barbara and Julia Muir. 2012. 'Chinese Investment in Latin American Resources: The Good, the Bad, and the Ugly. Peterson Institute for International Economics Working Paper No. 12-13. Washington, DC: PIEE.

Lall, Sanjaya. 1984. 'Exports of Technology by Newly-Industrializing Countries: An Overview.' World Development 12 (5-6): 471-480.

Lin, Yue. 2015. 'Firm Heterogeneity and Location Choice of Chinese Firms in Latin America and the Caribbean: Corporate Ownership, Strategic Motives and Host Country Institutions.' China Economic Review 34: 274-292.

Liou, Chih-shian. 2009. 'Bureaucratic Politics and Overseas Investment by Chinese State-Owned Oil Companies.' Asian Survey 49 (4): 670-690.

Little, Paul E. 2013. 'Megaproyectos en la Amazonia: un análisis geopolítico y socioambiental con propuestas de major gobierno para la Amazonia.' Lima: Red Jurídica Amazónica (RAMA), Articulación Regional Amazónico (ARA), Derecho, Ambiente y Recursos Naturales (DAR).

Lyman, Princeton N. 2005. 'China's Rising Role in Africa.' Council on Foreign Relations [online]. 21 July. At https://www.cfr.org/report/chinas-rising-role-africa [Accessed on 12 May 2014]. 
Medeiros, Carlos Aguiar de and Maria Rita Vital Paganini Cintra. 2015. 'Impacto da Ascensão Chinesa sobre os Países Latino-Americanos.' Revista de Economia Política 35 (1): 28-42.

Meyer, Klaus E and Saul Estrin (eds). 2006. Acquisition Strategies in European Emerging Markets. London: Palgrave Macmillan.

Moreno, Camila. 2015. O Brasil made in China: para pensar as reconfigurações do capitalism contemporâneo. São Paulo: Fundação Rosa Luxemburgo.

Morris, Jonathan, John Hassard and Jackie Sheehan. 2002. 'Privatization, Chinese-Style: Economic Reform and the State-Owned Enterprises.' Public Administration 80 (2): 359-373.

Nobre, Fábio Rodrigo Ferreira. 2014. 'Recursos Naturais na Região Amazônica: Cooperação ou Conflito?' Revista Política Hoje 23: 65-91.

O Correio News [online]. 2016. 'Grupo Estatal Chinês BBCA Iniciou a Construção Fábrica de Processamento de Milho em Maracaju.' 13 April. At http://ocorreionews.com.br/portal/2016/04/13/ grupo-estatal-chines-bbca-iniciou-a-construcao-fabrica-de-processamento-de-milho-em-maracaju/ [Accessed on 20 April 2016].

Oliveira, Gustavo de L T. 2015. 'Chinese and Other Foreign Investments in the Brazilian Soybean Complex.' BICAS Working Paper 9.

Pereira, Enio Bueno, Fernando Ramos Martins, Samuel Luna de Abreu and Ricardo Rüther. 2006. Atlas Brasileiro de Energia Solar. São José dos Campos: INPE.

Punnet, Betty Jane and Oded Shenkar. 1996. 'International Joint Ventures.' In Betty Jane Punnet and Oded Shenkar (eds), Handbook for International Management Research. Oxford: Blackwell, pp. 429-452.

Reed, Alastair. 2013. 'China Fishery Bids $\$ 790$ Million for Fish-feed Maker Copeinca.' Bloomberg [online]. 24 June. At https://www.bloomberg.com/news/articles/2013-06-24/china-fishery-bids790-million-for-fish-feed-maker-copeinca-1- [Accessed on 20 January 2015].

Rocha, Frederico. 2015. 'Recursos Naturais e Estratégias de Desenvolvimento no Brasil.' In Nelson Barbosa, Nelson Marconi, Maurícion Canêdo Pinheiro and Laura Carvalho (eds), Indústria e Desenvolvimento Produtivo no Brasil. São Paulo: Elsevier, pp. 617-643.

Rugman, Alan M and Jing Li. 2007. 'Will China’s Multinationals Succeed Globally or Regionally?' European Management Journal 25 (5): 333-343.

Salidjanova, Nargiza. 2011. 'Going Out: An Overview of China’s Outward Foreign Direct Investment.' US-China Economic and Security Review Commission (USCC) Staff Research Report.

Santos, Breno Augusto dos. 2002. 'Recursos Minerais da Amazônia.' Estudos Avançados 16 (45): 123-152.

Semanaeconómica [online]. 2016. 'China Fishery Group se Acogió a Protección Contra Bancarrota en Nueva York.' 30 June. At http://semanaeconomica.com/article/sectores-y-empresas/pesca/192645-china-fishery-group-se-acogio-a-proteccion-contra-bancarrota-en-nueva-york/ [Accessed on 7 August 2016].

Sociedade Nacional de Agricultura (SNA) [online]. 2016. 'Cofco Encontra Erro Contábil na Operação Brasileira da Nidera.' 14 December. At http://sna.agr.br/cofco-encontra-erro-contabil-na-operacao-brasileira-da-nidera/ [Accessed on 18 December 2016].

Superti, Eliane. 2011. 'Políticas Públicas e Integração Sul Americana das Fronteiras Internacionais da Amazônia Brasileira.' Novos Cadernos NAEA 14 (2): 303-320. 
The Heritage Foundation. 2014. 'Overcriminalized.' At http://www.overcriminalized.org/ [Accessed on 15 October 2014].

United Nations Conference on Trade and Development (UNCTAD). 2012. World Investment Report 2012: Towards a New Generation of Investment Policies. New York/Geneva: UNCTAD.

Valor Econômico [online]. 2016. 'Fiagril Conclui Venda de Controle de Subsidiária para Empresa Chinesa.' 10 July. At http://www.valor.com.br/agro/4629679/fiagril-conclui-venda-de-controle-desubsidiaria-para-empresa-chinesa [Accessed on 20 September 2016].

. 2016. 'Cofco Compra Restante das Ações da Nidera.' 23 August. At http://www.valor.com.br/ agro/4683171/cofco-compra-restante-das-acoes-da-nidera [Accessed on 20 September 2016].

Van Agtmael, Antoine. 2007. The Emerging Market Century: How a New Breed of World-Class Companies is Overtaking the World. New York: Free Press.

Wang, Bijun, Rui Mao and Qin Gou. 2014. 'Overseas Impacts of China's Outward Direct Investment.' Asian Economic Policy Review 9 (2): 227-249.

Wesz Junior, Waldemar João. 2014. O Mercado da Soja e as Relações de Troca Entre Produtores Rurais e Empresas no Sudeste de Mato Grosso (Brasil). Doctoral Thesis, Universidade Federal Rural do Rio de Janeiro, Brazil.

Wilkinson, John, Valdemar João Wesz Junior and Anna Rosa Maria Lopane. 2016. 'Brazil and China: The Agribusiness Connection in the Southern Cone Context.' Third World Thematics: A TWQ Journal 1 (5): 726-745.

Wilson, Ian Richard, Helena de Souza Santos, Pérsio de Souza Santos. 1998. 'Caulins Brasileiros: Alguns Aspectos da Geologia e da Mineralogia.' Cerâmica 44 (287-288): 118-129.

\section{Acknowledgements}

This work was developed in the scope of the Programa Institucional de Iniciação Científica (PROIC) (Institutional Scientific Initiation Programme) of the Federal Rural University of Rio de Janeiro. The undergraduate student in Economics Carla Gomes Costa was indispensable for the collection of the data and information presented and analysed in this article.

\section{About the authors}

Rubia Cristina Wegner has a Master's in Economic Development from the Economics Institute of the State University of Campinas and is a $\mathrm{PhD}$ candidate in Economics at the Federal University of Rio de Janeiro (UFRJ). Currently she is Assistant Professor and coordinator of the course of Economic Sciences at the Federal Rural University of Rio de Janeiro (UFRRJ). She was a scholarship holder of IPEA in the project 'Socioeconomic Structure and Policies for the Integration of South America.' She participated in the project 'Perspectives of Investment in Brazil' (BNDES) with the theme 'Investment Perspective on the Mercosur and Integration of Latin America'. She was a scholar in the project 'Brazilian Foreign Policy and the Development Challenges of Least Developed Countries - Haiti’s Case', funded by MCT/CNPq.

Marcelo Pereira Fernandes holds a PhD in Economic Sciences from the Fluminense Federal University (UFF/RJ). He holds an MA degree in Political Economy from the Pontifi- 
cal Catholic University of São Paulo (PUC/SP). He authored the book Exchange regime and macroeconomic performance the experience of Argentina, Mexico and Brazil in the 90s. Currently he is Associate Professor and vice-coordinator of Economic Sciences at the Federal Rural University of Rio de Janeiro (UFRRJ). He is also a member of the Federal Council of Economy (COFECON), the Research Group on Historical Patterns of Economic Development of South America, and the Interdisciplinary Laboratory of Studies in International Relations.

\section{Amazônia e a Internacionalização das Empresas Chinesas}

Resumo: O objetivo deste artigo é analisar o investimento direto externo anunciado e em curso de empresas da China na região amazônica, principalmente no Brasil, que contempla a maior parte da região, e no Peru. Traremos também em certa medida a região amazônica que atravessa a Colômbia e o Equador. Esses países constituem um dos eixos de integração sul-americana pela infraestrutura, e a construção de uma rodovia ligando o Peru e o Brasil ao Pacífico foi planejada. Segmentos como mineração, petróleo e grãos têm sido alvo da internacionalização produtiva das empresas chinesas. Nos países analisados, o volume de investimentos diretos anunciados e em andamento de empresas chinesas é de fato significativo, visando as indústrias de recursos naturais acima destacados. O grande projeto de infraestrutura anunciado será um apoio logístico para as empresas que anunciaram investimentos na Amazônia, especialmente entre o Brasil e o Peru. Mesmo que esses países e os outros cinco que compartilham a floresta amazônica tenham apresentado algumas propostas de cooperação, eles não desenvolveram uma abordagem comum para a recepção de investimentos de empresas chinesas.

Palavras-chave: Investimento Direto Externo, Empresa Multinacional Chinesa, Internacionalização, Integração, Amazônia.

Received on 19 February 2017, and approved for publication on 1 December 2017.

\section{(cc) BY-NC} https://creativecommons.org/licenses/by-nc/4.0/ 